\title{
Organized Crime in Kazakhstan: State and Solutions
}

\section{Kuandyk Zairullaevich Tokubayev}

\author{
Karagandy Academy of the Ministry of Internal Affairs of the Republic of Kazakhstan named by B. Beisenov
}

Email:tkz055@mail.ru

\section{Doi:10.5901/mjss.2015.v6n3s3p329}

\section{Abstract}

The article deals with the problem of organized crime in the Republic of Kazakhstan. Currently, organized crime is a major factor of the political and socio-economic instability of the state. One of the reasons of the circumstances existing in the field of combating organized crime is the insufficient scientific analysis of the problem, the lack of clear ideas about the strategy and ideology of the fight, as well as legal, criminological, forensic, and investigation concepts for identification, detection, investigation, and prevention of organized crime. In writing this report, the author pursued the following objectives: to review and analyze current issues related to organized crime; to justify the need to improve the measures for combating organized crime based on the analysis of the international experience and the views of scientists. As a result of the research, the author has come to the following conclusions: improvement of measures for combating organized crime needs solving a number of organizational and legal issues. They include development of a unified government strategy to combat organized crime, involvement of the whole society in the struggle against this crime, as well as the study and implementation of the international experience. When developing a domestic regulatory act for combating organized crime under the criminal law, one should rely on some of the key ideas contained in the RICO Act.

Keywords: crime, organized crime, a criminal organization, combating organized crime, unified national strategy for combating organized crime.

\section{Introduction}

Problems of crime control have always interested humankind. People live in fear of crime, and as long as there is a human society, it seeks ways and means to combat it. If we estimate the criminal problems and arrange them in a certain order according to the degree of public danger, one of the most real and dangerous criminogenic threats is organized crime.

Today, the state and society are confronted by persistent criminal organizations seeking to put themselves above the law, having their own systems of protection from social and legal control, which are based on violence and corruption. Organized crime ensures the existence and development of the "shadow" economy generating huge financial flows that are not controlled by the state or society. Organized crime actively expands its presence in legal business, undermines the principles of fair business, and impedes implementation of market reforms. Organized crime penetrates into authorities and management, public associations and political parties, which creates a threat of criminal infection of these structures and their invasion by representatives of the criminal environment.

Activity of organized criminal groups and trends of organized crime development actually threaten the national security and economic growth of the country, as well as the long-term priorities announced in the message of President Nursultan Nazarbayev to the people of Kazakhstan "Kazakhstan-2050" (Republic of Kazakhstan, 2012), which requires adoption of adequate preventive measures based on the study of the current state of this anti-social phenomenon.

The problem of combating organized crime has been researched in the publications of many legal scholars, such as Agapov, P.V. , Akimzhanov, T.K. Antonyan, Yu.M. , Arrastia, J. , Aslahanov, A.A. , Baraeva, N.B. , Bazilov, A.N. , Borisova, S.V. , Bykov, A.V. , Dolgova, A.I. , Galaktionov, E.A. , Gauhman, L.D. , Grib, V.G. , GureveB, M.S. , Gurov A.I. , Hristjuk, A.A., Kustov, A.M. , Lapshin, D.V. , Maulenov, G.S. , Nomokonov, V.A. , Nurgaliev, B.M. , Osipkin, V.N., Ovchinskiy, V.S. , Ovchinskiy, V.S. , Repezkaya, A.L. , Shelli, L. , Verbovaya, O.V., Vodko, N.P. et al.

However, it should be noted that today the organized crime problem has not been fully explored. There is a need in formation and improvement of certain legal regulations, development of new and improvement of existing countermeasures.

The study of the works of domestic and foreign scientists shows that one of the main controversial issues is the unity in understanding organized crime. Thus, the existence of organized crime "at the intersection of" the general 
criminal, economic, and corruption crimes was directly or indirectly indicated by P.V. Agapov (Agapov, 2013), T.K. Akimzhanov (Akimzhanov, 2000), A.A. Aslakhanov (Aslakhanov, 2004), and other authors. In her turn, N.B. Baraeva, when describing organized crime, concluded that an organized criminal group tends only to control legal economic structures, acting as a business entity (Baraeva, 2002) However, as rightly pointed out, it is very difficult, almost impossible to give a comprehensive concept of organized crime, which would reflect both criminological, forensic, and criminal law aspects (Yablokov, 1996).

Thus, despite the large number of studies on the problems of organized crime, the problem is not fully understood. There is a need in formation and improvement of the conceptual development of new and improvement of existing countermeasures. These circumstances predetermined the choice of the topic, as well as the general direction of scientific work.

\section{Methodology}

The theoretical basis of the study were scientific works of Kazakhstani and foreign scientists who contributed to the study of this problem in terms of improving the struggle against organized crime through the development and improvement of criminological and criminal law positions.

The empirical base of the research included the statistics of the Committee for Legal Statistics and Special Records of the General Prosecutor of the Republic of Kazakhstan (hereinafter - CLSSR GP RK) on the offenses committed by organized groups over the last five years, as well as offenses involving allegations of creation and management of an organized group, a criminal organization, as well as participation in them (Article 235 of the Criminal Code of the Republic of Kazakhstan (hereinafter - CC RK) (Republic of Kazakhstan, 2014).

In the course of the study, we examined international conventions and treaties, the criminal legislation of Kazakhstan and foreign countries, and other regulatory acts. Scientific periodical press materials discussing the issues of organized crime were also analyzed.

Results of the study suggest that organized crime is a social category. In this context, the study of this issue should start with criminological definition of the "organized crime" concept. In addition, the imperfection of the criminal law provisions, which reveal some characteristics of organized crime, greatly complicates combating it, is not conducive to the development of legislation that would ensure legal regulation of relations arising in this sphere.

However, studying organized crime, it is important to understand that it is not just about the increasing negative changes in the crime, but its acquisition of fundamentally new features characterizing the structure of the modern organized crime and largely determining its level and trends.

In recent years, the quantitative growth of organized crime led to further structural changes in the direction of the scale of organized forms, formation of stable gangs and criminal organizations focused on a certain type of criminal activity, in particular, on the economy, business, threats of terrorism, and religious extremism.

Law enforcement practice shows that one-third of criminal offenses, the most serious and dangerous ones, are committed in complicity. According to CLSSR GP RK, organized groups committed 1,323 offenses in 2012 and 949 offenses in 2013 in Kazakhstan. Analysis of the convicts structure indicates an increase in the number of convicts committed crime in an organized group of persons -by 0.4\% (in $2014-401$ (1.6\%), in $2013-327(1,2 \%)$ ) (General Prosecutor of the Republic of Kazakhsta, 2014).

One of facts evidencing the presence of organized groups is an act, for which the law provides responsibility for the creation and governance of an organized group, a criminal organization, as well as participation in them (Article 262 of CC RK).

According to CLSSR GP RK, 258 criminal cases were initiated under Article 262 of CC RK during 2010-2014. At the same time, statistics shows annual growth in this type of crime: in 2010, criminal prosecution bodies had 77 criminal cases pending under Article 262 of CC RK, in 2011 - 76, in 2012 - 88, in 2013 - 126, and in $2014-109$ criminal cases (General Prosecutor of the Republic of Kazakhstan, 2014).

However, it should be noted that Kazakhstan constantly works to improve the measures of response to organized crime, which is a major factor that destabilizes the social life, hindering the implementation of socioeconomic development, and posing a threat to democracy and stability.

In particular, a number of key laws aimed at improving the legislation on combating organized crime were adopted with account of the provisions of the UN Convention on Transnational Organized Crime. They include the laws of the Republic of Kazakhstan "On Struggling Corruption" \#267 dated 02.07.1998, the Law of the Republic of Kazakhstan "On National Security" \#2710 dated 06.01.2012, the Law of the Republic of Kazakhstan "On Struggling Terrorism" \#416 dated 13.07.1999, the Law of the Republic of Kazakhstan "On Struggling Extremism" \#31 dated 18.02.1995, and others. 
On January 1, 2015, a new Criminal Code of the Republic of Kazakhstan came into force, which interprets a number of provisions of the institute of complicity in criminal offenses in a new manner. Major novels of criminal law are aimed at forming provisions of the new law so that, on the one hand, they would meet international standards in combating organized crime, and on the other -took into account the specific nature of the national legal framework.

The new CC RK in detail and consistently secured the most important aspects related to organized crime. The accumulated scientific and practical experience in combating organized crime allowed providing clarification of some concepts characterizing different forms of complicity in crime in Article 3 of CC RK. Some of them had belonged to valuation concepts and caused difficulties in classification. Now, with the inclusion of these definitions in CC RK, it is suggested that this will help to reduce errors in law enforcement.

In the Criminal Code, such forms of participation as an organized group, a criminal organization, a criminal community, a transnational organized group, a transnational criminal organization, a transnational criminal community, a terrorist group, an extremist group, a gang, an illegal armed group are covered by a single notion of "criminal group" (Article 3 Clause 24 of CC RK).

The concept, types, responsible partners, as well as features of criminal responsibility at various forms of participation are governed by Articles 27-31 of CC RK. New forms of complicity such as a gang, an illegal armed group have been introduced.

According to Article 3 Clause 7 of CC RK, a gang is understood as an organized group aiming to attack individuals or organizations threatening to use weapons or objects used as weapons.

According to Article 3 Clause 18 of CC RK, an illegal armed group is a group (association, detachment, brigade, or other group, consisting of three or more people) not provided for by the legislation of the Republic of Kazakhstan, which has the organizational structure of a paramilitary type, unity of command, combat capability, and rigid discipline.

According to Article 3 Clause 23 of CC RK, a criminal community is a union of two or more criminal organizations that have entered into an agreement for joint commitment of one or more criminal offenses, as well as to create conditions for unassisted commitment of one or more criminal offenses by any of these criminal organizations.

Article 3 Clause 32 of CC RK describes in detail the concept of a person holding a leading position -a person endowed by the leaders of organized groups (criminal organizations) with the authority to coordinate criminal activities, or a person, who is recognized by the group members as having the right to take the most important decisions affecting their interests and determine the direction and nature of their criminal activity.

Article 266 of CC RK specifies the notion of financing the activity of a criminal group, as well as storage, distribution of property, development of financing channels, which greatly facilitates classification of these crimes during their investigation.

In addition, CC RK contains stricter criminal punishment. For example, the only punishment for offenses committed by organized criminal groups is imprisonment, and for involvement of minors in criminal activity (Article 132 Part 5 of CC RK), the punishment is 10 to 15 years of imprisonment with a lifetime disqualification from holding certain positions or engagement in certain activities. Punishments in articles providing liability for extremist offenses committed by a criminal group have been worsened and moved to the category of extremely grievous crimes (Article 174 Part 3 of CC RK, Article 256 Part 2 of CC RK, etc.).

\section{Discussion}

As noted above, to date there is no consensus about the definition of "organized crime", both in law enforcement practice and among legal scholars. Scientific, journalistic, and even detective literature give many definitions, but do not suggest a unified scientific definition of organized crime.

The international community is engaged in the problem of defining organized crime since mid-1970s. The most intensive work in this direction was done during the preparation of the Eighth United Nations Congress on the Prevention of Crime and the Treatment of Offenders (Havana, Cuba, August 27 -September 7, 1990). The document prepared by the Secretariat of the United Nations noted that one formulation is not enough to reflect all manifold manifestations of organized crime. Overall, however, it can be defined as "sophisticated criminal activities conducted on a large scale by organizations and other groups that have an internal structure, gain financial profit, and gain power through the creation and exploitation of markets of illicit goods and services."

The document prepared based on the UN International Seminar on the Control of Organized Crime (Suzdal, USSR, October 21-25, 1991) pointed out that organized crime should be understood as a relatively large group of sustainable and controlled communities of criminals committing offenses on a regular basis and creating a system of protection from social control using illegal means such as violence, intimidation, corruption, and large-scale fraud. 
The report of the UN Secretary General "The impact of organized criminal activities upon society at 1arge" in the second session of the Commission on Crime Prevention and Criminal Justice of the Economic and Social Council of the UN on 13-23 April 1993 gave a generalized characteristic of organized crime and listed its inherent features:

- organized crime is a confederation of criminal individuals or groups that come together because of economic needs;

- organized crime involves conspiratorial criminal activity, usuallyinvolving the hierarchical coordination of a number of persons in the planning and execution of illegal acts or in the pursuit of legitimate objectives by illegal means;

- organized criminal groups have a tendency to establish a monopoly or near-monopoly in providing illegal goods and services to customers, since higher profits are guaranteed in this manner;

- organized crime does not limit itself to patently illicit undertakings or illegal services. It also includes such sophisticated activities as money laundering through legitimate business and computer manipulation. It infiltrates many kinds of profitable, legal endeavours;

- organized crime uses predatory tactics, such as intimidation, violence, and corruption. These tactics may be sophisticated and subtle, or crude, overt and direct. They are used to secure economic gain through a monopoly inillegal goods and services, as well as to infiltrate legitimate enterprises and to corrupt public officials.

According to V.S. Ovchinsky, organized crime is not only and not so much a collection of different organized communities, it is also a form of life activities of individuals, groups of individuals, whose individual behavior and lifestyle reproduce the patterns of behavior and lifestyle of criminal organizations (Ovchinski, 2003).

A.I. Dolgova suggested the following definition of organized crime: organized crime is a complex system of organized criminal groups, their relationships and activities (Dolgova, 2011).

A.V. Bykov said that the main attribute of organized crime is the "structural" one, which means an association of persons with the purpose of the systematic commitment of crimes. The attribute implies unity, stability of the established criminal structures, and presence of a hierarchy among members of groups (Bykov, 2013).

As rightly pointed by V.A. Nomokonov, combating organized crime needs reasonable borrowing of advanced foreign experience (Nomokonov, 2014).

In consideration of this issue, criminal legislation of a number of foreign countries is of great interest, as it clearly defines "organized crime" as the most dangerous social phenomenon.

The experience of the USA, where the famous "Organized Crime Control Act" was adopted in 1970, is also noteworthy. Largely, this law is considered as one of the most effective tools for the criminal law to combat organized crime. Since the entry into force of the RICO Act, the number of criminal cases against members of organized crime groups significantly increased in the USA. Among others, members of New York's five "families" of "Cosa Nostra" were subjected to criminal prosecution, as well as criminal gangs in many other US cities (Cormaney, 1997).

The most important of its provisions is Paragraph 1962, which criminalizes the very fact of participation in criminal communities. In addition, Section IX of the Racketeer Influenced and Corrupt Organizations Act is textually included as Chapter 96 in Section 18 of the US Code (Shelli, 2010).

The US Federal law defines organized crime as "the unlawful activities of the members of a highly organized, disciplined association engaged in supplying illegal goods and services, including but not limited to gambling, prostitution, loan sharking, narcotics, labor racketeering, and other unlawful activities of members of such organizations." It should be noted that organized crime in many US states is defined differently, but the bottom line is reduced to the existence of an organization(s), the subculture established in it, and to engagement in criminal business. Herewith, definitions often contain elements that characterize not organized crime as a social phenomenon, but criminal law attributes determining the concept of organized crime. In particular, the State of California understands organized crime as an act that is being committed by two or more persons for a long time. The following is a list of the five crime areas: 1) racketeering; 2) immoral actions (illegal services -prostitution, drugs, gambling); 3) sale of stolen goods; 4) gangs; 5) terrorist groups. The State of Delaware understands it as a group acting outside the law in order to obtain material benefits for themselves (Dolgova, 1993).

As you can see, organized crime is estimated differently even by law enforcement and legislative bodies of the same state, where it has reached considerable size and penetrated in the sphere of economics and management.

German police defines organized crime as follows: "... based on the division of labor, willful, deliberate, ongoing long-term cooperation of several (many) people aimed at committing criminal (punishable) actions -often using modern infrastructure -with a view to possibly more rapid extraction of high incomes."

In Belgium, organized crime is understood as planned commitment of offenses dictated by the desire for profit or 
power (each or all of which represent high public danger): by two or more persons; for a prolonged or indefinite period; with division of criminal functions, as well as:

a) using business structures or structures similar to them, or;

b) using force or threat of force, or;

c) influencing on politics, mass media, society, justice, or the economy.

Progressive provision is contained in Article 324 Paragraph 2 of the Criminal Code of Belgium. It states that any person who participates in the commitment of any lawful activities of a criminal organization, knowing that his actions contribute to its operation, may be sentenced to one to three years of imprisonment or a fine up to five thousand euros.

This evidences the fact that the criminal law of Belgium is directed against those persons (entities) who do not formally come into contact with the criminal activity, and are the legally functioning divisions of organized groups. Primarily, these economic structures are created to "launder" the proceeds of crime.

The analysis of the views of scientists and international regulations allowed concluding that the approach to the concept of organized crime and its definition in international documents are virtually identical. However, in contrast to other countries, in which there is a clearly built legislative framework of combating organized crime, Kazakhstan still needs it to be enshrined in the law. At the same time, the phenomenon exists and the law of Kazakhstan (Article 262 of CC RK) regulates the punishment for it, depending on the degree of danger to the society's security (an organized group, a criminal organization).

Thus, in Kazakhstan, there is yet no single definition of organized crime and research on this topic is conducted separately by individual specialists. The absence of such a concept in law leads to different understanding of its essence and is not focused on effective control of its manifestations. Moreover, the Kazakhstani legislators have not yet developed special legislation to combat organized crime, which does not allow solving the problems of its control.

\section{Conclusions}

The study reviewed current problems of combating organized crime in the Republic of Kazakhstan and a number of other countries. The author, based on the analysis of the current legislation of the Republic of Kazakhstan, concludes that the domestic legal framework for combating this criminal phenomenon is insufficient. The state through its public authorities should determine the guidelines of the fight, its main priorities, goals, and objectives, shape the regulatory framework of the fight, provide planning, control, and coordination of measures to implement the combating policies on a national scale. That is why the principles of operation of public authorities regarding combating organized crime should be regulated at the level of a national program.

In order to address the above problems, taking into account the international law and the laws of foreign countries, we consider it necessary to adopt the Concept of combating organized crime. This Concept is necessary as a system of coordinated, science-based views on the problem and ways to solve it. It should be aimed at improving the information support for the optimization of the legal framework, undertaking specific coordinated joint activities of law enforcement and other bodies.

The concept of combating organized crime should be based on an analysis of the crime rate, a forecast of the development of organized crime, and the practice of combating organized forms of crime. It should disclose the measures for improvement, review, and revision of legislation and institutional framework of combating organized crime. Herewith, it is necessary to take into account the international experience and the level of legal consciousness. General and special prevention of this crime should be clearly defined as a priority line to combat this negative phenomenon. With account of today's realia and international experience, we need to provide provisions encouraging offenders to cooperate actively with law-enforcement agencies.

In combating organized crime, it is necessary to develop international cooperation, as well. Thus, an extension of intergovernmental agreements on reciprocal enforcement of international investigative and search orders for crimes committed by organized groups is needed. Interpol should intensify its activities in this part, in particular, in the international exchange of information on the size, composition, crime classification, and transnational nature of organized crime groups.

In combating organized crime, it is necessary to combine logically certain legal norms regulating the activities related to combating organized crime and sc

attered across numerous regulations, using the best practices of other countries, the vivid example of which is the RICO Act (Hristjuk, 2013).

The RICO Act, which was enacted in 1970, is the main piece of legislation on the issues of combating organized crime. According to Paragraph 1962 of the RICO Act, the fact of participation in criminal communities is acknowledged 
organized crime, which helps indict and convict the leaders of criminal groups.

The main objective of the RICO Act is to destroy organized crime in the United States by consolidating legal instruments in the process of evidence gathering, establishing legal prohibitions, imposing enhanced sanctions, and introducing new remedies in combating illegal actions of individuals involved in organized crime (Arrastia, 1996).

Thus, to improve measures for combating organized crime, it is necessary to resolve a number of organizational and legal issues. They include development of a unified government strategy for combating organized crime, involvement of the whole society in combating this crime, as well as the study and implementation of the international experience. When developing a domestic regulatory act for combating organized crime under criminal law, one should rely on some of the key ideas contained in the RICO Act.

\section{References}

Agapov, P.V. (2013). Bases of combating organized crime (Extended abstract of Doctor's thesis). Academiya Generalnoi prokuraturi Rossiiskoi Federazii (p. 15). Moscow.

Akimzhanov, T.K. (2000). Organized crime - an independent type of crime. Problems of the Fight against Crime and Corruption (pp. 1922). Karaganda: Karagandinskaya vischaya shkola MVD RK.

Aslahanov, A.A. (2004). About the Russian mafia without sensationalism (Reflections of the major general of militia) (pp. 61). St. Petersburg: "Yuridichesky Center Press".

Antonyan, Yu.M. (2011). Osobo opasniy prestupnik [Dangerous criminal].Moscow: Prospect [in Russian]. 312 p.

Arrastia, J. (1996). Money laundering —a VS perspective. Money laundering control (Rider, B., \& Ashe, M., Eds., pp. 228-260). Dublin: BAW.

Bazilov, A.N. (2001). Kriminalisticheskoe obespechenie rassledovaniya organizovannoi prestupnoi deyatelnosti [Providing forensic investigation of organized crime]. Extended abstract of candidate's thesis. Karaganda: Karaganda Higher School of the MIA of the RK.

Borisova, S.V. (2006). Ugolovno-pravovie i kriminologicheskie problemy borby s banditizmom [Criminal law and criminological problems of struggle against gangsterism]. Extended abstract of candidate's thesis. Moscow: Moscow State Linguistic University.

Baraeva, N.B. (2002). Concept and characteristics of organized crime. Retrieved from http://deviantology.spb.ru/etc/publications/ Baraeva-Ponyatie_i_priznaki_organizovannoy_prestupnosti.pdf

Criminal Code of the Republic of Kazakhstan of July 03, $2014 \# 226$.

Dolgova, A.I., \& Dyakov, S.V. (1993). Organized crime (pp. 146-147). Moscow: Russian criminological association.

Information service of the Legal Statistics and Special Records Committee of the General Prosecutor of the Republic of Kazakhstan. (n. d.). Website Pravstat.kz. Retrieved August 15, 2014 from http://service.pravstat.kz/

Galaktionov, E.A. (1993). Ugolovno-pravovie sredstva borby s organizovannoi prestupnostyu [Criminal legal means to combat organized crime]. Extended abstract of candidate's thesis. Moscow: Higher Correspondence Law School of the MIA of the RF.

Gauhman, L.D. (1993). Organizovannaya prestupnost: ponyatie,vidy, tenfenzii, problem ugolovno-pravovoi borby [Organized crime: concept, types, trends, issues of criminal legal fight]. Kiev: Ин-т держави і права АН Украіні.

Grib, V.G. (2001). Protivodeistvie organizovannoi prestupnosti[Combating organized crime]. Moscow: INFRA-M.- $94 \mathrm{p}$.

GureveB, M.S. (2000). Metodica rassledovaniya ubistv, sovershennich v otkritich stolknoveniyach mezhdu organizovannimy prestupnimi gruppami [Methods of investigation of murders committed in open clashes between organized crime groups]. Extended abstract of candidate's thesis. Saint-Petersburg: Saint- Petersburg Law Institute of the General Prosecutor's Office of the Russian Federation.

Gurov A.I. (1990). Professinolnaya prestupnost: proshloe i sovremennost [Professional crime: Past and Present]. Moscow: Legal literature. 301p.

Kustov, A.M. (1999). Mechanizm deyatelnosti prestupnogo soobschestva( prestupnoi organizazii) po sovershenuyu prestuplenii । deyatelnosti po protivodeistviyu rassledovaniyu [The mechanism of activity of a criminal association (criminal organization) for committing crimes and activities to combat Inquiry]. Karaganda: Karaganda Higher School of the MIA of the RK.

Letter from the President of the Republic of Kazakhstan, the Leader of the Nation N.A. Nazarbayev to the people of Kazakhstan "Kazakhstan-2050 Strategy": New state political course" (2012, December 14). Astana. Retrieved June 25, 2014, from http://adilet.zan.kz/rus/docs/K1200002050

Ovchinskiy V.S., Eminov, V.E., \& Yablokov, N.P. (1996). Basis of the fight against organized crime. Moscow: INPA-M.

Law of the Republic of Kazakhstan "About struggle against corruption" dated 18/01/2012 \#547-IV. Retrieved from http://adilet.zan.kz/rus/ docs/Z1200000547

Law of the Republic of Kazakhstan "On National Security" dated 06.01.2012 \#527-IV. Retrieved from http://adilet.zan.kz/rus/docs/ Z1200000527

Law of the Republic of Kazakhstan "On Suppression of Terrorism" dated 13.07.1999 \#416. Retrieved from http://adilet.zan.kz/rus/docs/ Z990000416

Law of the Republic of Kazakhstan "On Countering Extremism" dated 18.02.2001 \#31. Retrieved from http://adilet.zan.kz/rus/docs/ Z050000031

Ovchinskiy, V.S. (2010). Russian organized crime (Mafia) as a form of social organization of life. Retrieved from http://zpu-journal.ru/e- 
zpu/2010/3/Ovchinsky/

Dolgova, A.I. (2011). Criminological estimations on organized crime and corruption, legal battles and national security (pp. 288-300). Moscow: Russian criminological association.

Bykov, A.V. (2013). Organized crime and local government. Criminology Journal of Baikal National University of Economics and Law, 4, $163-168$.

Nomokonov, V.A. (2014). The fight against criminal organizations: the American experience and the realities of Russia. Criminology Journal of Baikal National University of Economics and Law, 4, 46-53.

Shelli, L. (2010). Transnational organized crime in the United States: definition of the problem (pp. 96-114). Repezkaya, A.L. (2001). Transnazionalnaya organizovannaya prestupnost [Transnational organized crime]. Extended abstract of Doctor's thesis. Moscow: Russian Academy of Sciences. Institute of State and Law.

Vladivostok : Издательство Дальневосточного университета.

Hristjuk, A.A. (2013). Current trends and main direction of organized crime counteraction. Criminology Journal of Baikal National University of Economics and Law, 3, 115-120.

Verbovaya, O.V. (2000). Ugolovno-pravovaya borba $s$ banditizmom v Respublike Kazakhstan [Criminal legal fight banditry in the Republic of Kazakhstan]. Extended abstract of candidate's thesis. Almaty: Academy of the MIA of the RK.

Vodko, N.P. (2000). Ugolovno-pravovaya borba s organizovannoi prestupnostuyu [Criminal legal fight against organized crime]. Moscow: Jurisprudence. $73 \mathrm{p}$. 
ISSN 2039-2117 (online) ISSN 2039-9340 (print)
Mediterranean Journal of Social Sciences MCSER Publishing, Rome-Italy
Vol 6 No $3 \mathrm{~S} 3$ May 2015 